\title{
MANAGEMENT CONTROL IN IMPLEMENTATION OF THE SOCIAL PROGRAM
}

\author{
Venelin Terziev ${ }^{1}$, Marin Georgiev ${ }^{2}$, Denis Solovev ${ }^{3}$ \\ ${ }^{1}$ Full Member of the Russian Academy of Natural History, Professor, Eng, \\ D.Sc. (National Security), D.Sc. (Economics), D.Sc. (Social Activities), Ph.D., Russian Academy of \\ Natural History, Moscow, Russia, Vasil Levski National Military University, Veliko Tarnovo, Bulgaria \\ University of Rousse, Rousse, Bulgaria, terziev@skmat.com \\ ${ }^{2}$ Ph.D., National Military University, Veliko Tarnovo, Bulgaria, clementon@abv.bg \\ ${ }^{3}$ Associate Professor, Ph.D., Far Eastern Federal University (FEFU), Vladivostok, Russian \\ Federation, solovev.db@dvfu.ru
}

\begin{abstract}
The research discusses its linkage to the notion of control in contents and functional aspects as a function of management and as a form of social relation introducing the concepts of management control and social control substantiated by the main functions of management and presenting the process of the implementation of control function positioning the management control into the social system. Furthermore, the control functions are scrutinized in connection to its turning into a factor generating ideas of change and innovativeness, a main factor of success and establishment of integrated control systems.
\end{abstract}

Keywords: control, management, social program, social programming, functions of management.

\section{INTRODUCTION}

In its multiple meaning, the word "programme" is widely penetrating in the field of social life and is also understood as list, index, notes (of theatre, concert performances, performed roles and their performers, in radio and television broadcasts, of authors of reports, scientific conferences and symposia), etc. Namely the potential range of application of that term is the grounds for transferring its general meaning upon wider and wider fields of applicability, within which frames to define its aspect meaning and content. For the aims of our study, we determine the term "programme" in the aspect of a certain public activity, what social activity is. We use the concept "social programme" in this sense, which definition finds manifestation in several aspects (Terziev, 2013; Terziev, 2014):

The social programme is a perspective concept for the growth of wealth and development of social relations. It gives general characteristics of the country's social development within a particular historic period, the main directions for increasing the wealth and the global quality and quantity indicators that are to be reached for the period. Leading parties' programme documents contain such concepts that serve as base for elaborating the relevant sections of the economic and social development plans.

Social programmes appear to be special sections of the economic and social development plans (yearly or for a longer period) of the corresponding planning regions, districts and municipalities. Deeper reflecting the 
perspective social reference points, they form the tasks for a certain stage and the ways to achieve them, reflect the deeper introduction of social criteria in planning, in economic growth as a whole and of its single sections. More, they appear to be not only end result of the economic development's planning but being also a complex of knowledge about it.

The special social programmes that suggest solution of particular social problems of crucial significance and corresponding concentration of resources emerge. In this sense the term "social programme" is wider used, nevertheless it refers to a narrower concept. Often, such programmes concern various sections of the socialeconomic plans and require special coordination in the development of the various branches of national economy.

Social programmes contain specification of the goals and tasks, reflect their hierarchy, serve for forming new forms of satisfying population's social needs and for creating of corresponding new organization connections. The combination of outlined and feasible actions (measures) in one or another social field can be quite reasonably be reviewed in the capacity of a social programme, in this case, if they haven't got unified programming document, plan, etc., but grounded on a common concept, interconnected and directed towards achieving one complex goal. The pointed qualities of social programmes such as conceptuality, targeting for satisfaction of social needs, including new forms, defining the reference points in the social development, the social criteria in economy's progress, their expression in quality and quantity indicators, type diversity and social flexibility, allow to be found as universal method for political and management activity. Using this method might vary depending on the general and specific social-economic, political and other circumstances.

Although recognizing the time in our society - the end of the 70s, social programmes are reviewed within the frame of the then existing system of party management and total state directive-based planning (Semenets, 1999). The term "target complex programme" has established itself in the political and management vocabulary since the 70 s, which is usually understood as "directive-based and addressing document, which is bound to resources, executors and time terms for conducting a complex of interrelated tasks and actions, united by a common goal" (Semenets, 1999).

Recognizing the significance of such programmes in the practice of managing, it is necessary to note that their general name is far not the most proper. The adjectives "target" and "complex" characterize the attributive, immanent features of each programme, not of the ones of the particular class only. Non-target and non-complex programmes simply do not exist. Each programme, openly or not, contains a goal and a certain number of or a complex of means for execution. This case confirms once more the necessity of terminological analysis and of finding and adequate definition. The term "programme" started being used by the American politicians and in the scientific circles for signifying part of the budgetary process, as a direction for financial funds for solving particular social and economic tasks. It is to be noted that in most of the aspect definitions there is identifying of the term for programme, with the term "plan", where there is merging of one of the terms into the other. A circle of definitions appears of the type "a programme, this is a type of programme", etc. The terms project, model, etc. are put within this circle, which interpretation is also changeable.

The identifying of the term "programme" with the term "plan" distorts the essence of the programme-targeted approach of management and the integrity of the management phases - planning, programming, budgeting. Each one of them has certain functions in the management process and has as result certain products. And if the phase planning gives answer to the question "what" (has to be done), the phase programming looks for answer to the question "when" (to be done), and the budgeting phase gives answer to the question "how much and what resources are necessary" (for what is to be done). The substantial is that these are the questions of each management process, united by the question "Why". This is the reason for the particularism of programming to be looked for as intermediate phase between planning (defining the longterm goals) and budgeting (specifying the interrelation of the goals and the resources insuring). And this, more or less, expresses the subordination "resources-capabilities-effects", which lays in the grounds of results-based management.

\section{MANAGEMENT CONTROL IN THE SOCIAL PROGRAMME IMPLEMENTATION}

The evolution of human society accepts the objective need of control. Its eventful history proves its significance as necessary attribute of social environment. The occurrence of control is connected with the first days of human consciousness. Its development and improvement are engaged with the human genius's achievements in social progress. Because of that fact, it is scientifically grounded the essence of control to be given meaning to and be displayed within the natural environment of social surrounding, which develops and enriches certain forms of manifestation. The essence of control is expression of the most important and 
significant side that defines the interior relative sustainability and depth of processes, phenomena, relations, manifested through the forms and methods of impact

Two statements about control that express its possibility to be form of social attitude and as function of management are chosen for the most complete and thorough clearing of the studied topic (Simeonov, 2005), and from there, for satisfying the preset goals. Human society accepts the objective need of control since the very beginning of its conscious progress. It introduces it and expresses it as attitude of the collective body, of the group of people towards the behaviour and individual capabilities of the single members of society to exactly meet the requirements of the adopted rules for equal participation at creating and using material wealth. Yet in this authentic and primitive expression of social attitude, two sides outline - subject in the person of the collective body, and object - the attitude of single individuals towards the method of production and distribution. Control preserves its essential characteristics as form of social attitude bound to a particularly grounded criticism in the next phases of social development. Regarding giving meaning to and positioning control as special form that reflects social attitude, we accept as most complete the statement that control is a critical social attitude grounded on the socially significant subordination "dominationsubmission", purposely engaged with limiting the freedom of a group of social subjects, with view to realizing the interests of another one or of another group of social subjects.

Complicating control as social attitude with certain criticism (Atanasov, 1968; Atanasov, Dinev, 1984) is connected with quality changes in the process of changing the method of production and distribution of public wealth. In the complicating social relations in the later phases of human society development, sharper and sharper the trend of individualization of the subject of control and its turning into function of the specially established institutions expresses. The ruling system forms its own apparatus and specifies its functionality depending on the interests for domination.

Control as socially balanced form that expresses the attitude of domination and submission predetermines the possibilities of the controlling one to limit the behaviour of the controlled one and to force him to observe certain norms. In that sense, the controlling one dominates over the controlled one, limiting his freedom in the name of realizing his own interest. The objective differences in the social subjects' potential found in their basic characteristics contain preconditions for establishing that power (Morgenthau, 1960; Dinev, Hristova, 1992 ) (fig. 1).

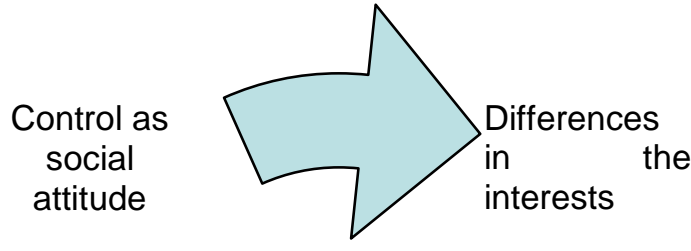

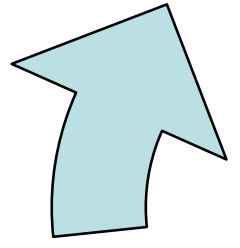

Attitude of domination and submission

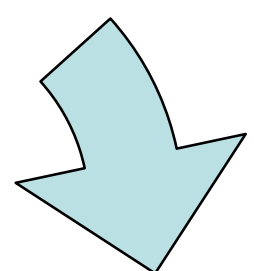

Critical attitude
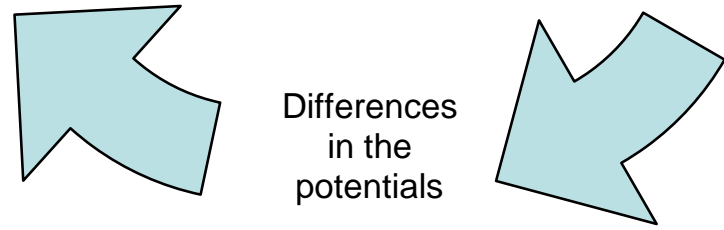

Fig. 1. Control as social attitude. 
Each economic system could be reviewed as combination of interrelated production processes that comprise separate operations, where certain subjects of labour are transformed into utility values (Mateev, 1987). The unity of processes and the operations forming them is organized in production-technological expedience of proved necessity and logical sequence of the connections between them. The fact that the economic system is modeled by processes and operations - a particular expression of premeditated human activity, given meaning to by relations of personalities and their formations, defines it as social organizational structure with production-functional purpose. The central problem of the social organization's analysis is to what an extent its structure and functioning effectively serve its production-functional purpose. For solving it, the economic systems' management should keep an eye on the production-technological expedience of the processes and operations included in the system as well as on their social side, the effective structuring of social relations, including the relations of control.

As a specific form of social attitude, the purpose of control is ensuring effective presence of human factor in the production-technological process. Control could be reviewed as an original, function-defined instrument for domination, objectively conditioned by the necessities of cooperated production in the conditions of division of labour (Marks, 1955). The objective necessity is set in the interests of the ones, whose monopoly is the conduction of organization and managerial functions.

Organized control neutralizes the possibilities for autonomy of executors, who serve the production processes. The compulsory nature of the control exercised upon the oppressed ones provokes unsatisfaction. This is natural reaction as expression of disagreement with the purposeful activity of organizations to devour and subordinate them according their goals (Etzioni, 1967; Robson, 2001a). In this sense, although certain resistance is registered, objectively it is accepted by necessity social impact as major circumstance for progress and improvement. Exercising control in each economic system, the possibility for registering and analyzing the level of certain factors is quite speaking for the process' effectiveness. First, the actual extent of real interest of the participating individuals and groups in the strict execution of the delegated functions and tasks. Second, the quality of execution at the lack of control. Third, the quality of execution at forced conduction of control actions.

Forming the view for the consequences of control, one should always consider that the productiontechnological expedience realization is result of disciplined behaviour of individuals and their groups as well as of the creativity, their activeness and initiative while realizing their functions in the organization. Control's content is defined by the immediate connection and the continuous interaction between the object and the subject, by their manifestation in the various forms of social management. The behaviour of the subject towards the object, the inside mechanisms of impact and interaction is defined by the development of the social environment, by its perfection. There is no doubt society and its structures (Dinev, 1986) need control. This is control that helps the improvement of social relations, focusing the power of impact upon the behaviour of the individual or the group of individuals united at achieving particular goal.

Social resonance of control and the feeling of unsatisfaction from it are historically objective and particularly defined by the cultural differences (Nakata, Sivakumar, 1996) of organizations, formed by the national cultural peculiarities (Vilkas, Mayminas, 1981) and the organization identity. The control that is exercised on the behalf of society regarding the individuals, who compose it, the social groups and organizations, is known as social control (Ross, 1969; Vilkas, Mayminas, 1981). It rests on the authority of the whole society and is realized through the apparatus it has, including the possibilities for domination and submission by the state.

Observing the social norms that ensure the entirety and sustainability of society, integrate the individuals, the groups and the social organizations in it, ensure the solving of socially accepted goals and tasks are defined as subject of social control. These norms, goals and tasks acquire the meaning of "social order" or "social contract". The fact of commonness itself is result of a compromise with view to avoiding conflicts and preserving the society. In this context, social control is called upon ignoring and regulating the confrontation of individuals and social formations. It is product of the social consensus, which is achieved in order to avoid conflicts. Social control's task is to regulate deviating behaviour (Durkheim, 1966; Merton, 1957; Dinev, Donev, 1989), which is in contrast with the dominating way of life and breaks legal, moral, political, religious, ethnic and other social norms. At some stage in its development, society creates a structure and organization of government as its own internal mechanism for action. The differences in the various social economic formations are result of changed correlations in the method of production and consumption, of contradictions expressed by the form of power and governing. Human evolution is result of building and improvement of a particular structure of society, based on a definite way of objective, useful, personal participation to a particular stage of public production. The structure fixes the dynamics, the movable side of social development and preconditions its possibilities for achieving certain goal. In the management theory, there are a lot of definitions of the term "management", but there is no one satisfying all points of view. 
Certain theorists give meaning to the term "management" by binding it to social transformations and accept that: "management is a special type of activity that turns unorganized crowd into effective productive group" (Drucker, 1974). Another group of experts, reviewing the human society evolution, connecting it with the development and improvement of certain, public organizations and structures, suggest the definition: "management is a purposeful and effective process for achieving the organization's goals through planning, organizing, motivating and control upon organization's resources" (Stoner and Freeman "Management", 1989a). An essential moment in this statement is the combining of the basic management functions planning, organizing, motivating and control, with the effective and rational achieving of organization's actual goals (tabl. 1).

Table 1. Functions of management (Daft, 2005).

\begin{tabular}{|c|c|c|c|}
\hline \multicolumn{4}{|c|}{ Functions of management } \\
\hline \multicolumn{3}{|c|}{ Organization resources: } \\
Human; Financial; Material; Technological; Information, etc. \\
\hline $\begin{array}{c}\text { Planning } \\
\text { Selection of goals and } \\
\text { defining a way for } \\
\text { achieving them }\end{array}$ & $\begin{array}{c}\text { Control } \\
\text { Observation for } \\
\text { conducting actions and } \\
\text { Corrections }\end{array}$ & $\begin{array}{c}\text { Motivating } \\
\text { motivating the } \\
\text { executors }\end{array}$ & $\begin{array}{c}\text { Organizing } \\
\text { Distribution of } \\
\text { responsibilities } \\
\text { regarding execution of } \\
\text { work tasks }\end{array}$ \\
\hline \multicolumn{3}{|c|}{ Results from the activity: } \\
\hline \multicolumn{2}{|c|}{ Achieved goals; Stock; Services; Productivity; Effectiveness, etc. } \\
\hline
\end{tabular}

The purpose of control, as function of management, is to ensure the realization and the up-date of the given target function of the managed system on the grounds of the principle of feedback. According to that principle, management could be exercised only when the governing ones receive information about the course of reaching the given status. The discrepancy of the actual status to the given one is that correcting signal that provokes change in the management and finds expression through several forms:

- Improvement of execution, undertaking regulative measures for a stricter observation of the specified standards for activities of execution;

- Changes in the standards for the activities with view to their complete adequacy to the set goals;

- Correcting the given meanings of the manageable variables included in the target function; changes in the structure of the given target function.

The process of realizing controlling function passes through two main stages, and several substantial phases are registered within them (Taylor, 1911):

- Preparatory stage

$\checkmark$ Evaluation of the planned status;

$\checkmark$ Defining standards for admissible deviations.

- Real stage

$\checkmark$ Measuring the factual status;

$\checkmark$ Comparing the factual with the planned status and diagnostics of deviations; regulation.

The flowing of the control process in the organization is regulated through internal standard for control. The standard embraces the technological procedures of implementing the control activities as well as the responsibilities of the various hierarchical sections and time horizons of the control effects (tabl.2). 
Table 2. Theoretic model of the control process.

\begin{tabular}{|c|c|c|}
\hline \multicolumn{3}{|c|}{ Theoretic model of standard of control process: } \\
\hline $\begin{array}{c}\text { Evaluation of the standard for } \\
\text { planning and prognosticating of } \\
\text { the plan's execution }\end{array}$ & $\begin{array}{c}\text { Elaboration of variants for } \\
\text { admissible deviations and } \\
\text { evaluation regarding the } \\
\text { selection of variants }\end{array}$ & $\begin{array}{c}\text { Measuring the meaning of } \\
\text { variables }\end{array}$ \\
\hline Evaluation of the planned status; Defining standards for admissible deviations; Measuring of factual \\
status.
\end{tabular}

The analysis of control as function of management wouldn't be complete if it does not include its perimeter of action and its connections with the other types of control that function and regulate the activity of each organization are not given meaning to. The roots of control as function of management could be found yet in early samples of managerial thought (Worthy, 1950), and each next sample enriches and develops further the meaning of control in content and functional aspect. Its essence and organized nature, as range of its forming stages and their placement and going within time define it as process through which the governing ones make sure the resources are acquired and used effectively and efficiently for achieving the organization's goals (Dinev, Donev, 1989; Dinev, Hristova, 1992). The combination of activities in control's development, as function of managing, going in the form of a process, are logically organized as sequence. The algorithm of carrying out rests on the grounds of rationalized reasonability and certain regularity, which form the process as specific organizational system. In the organizational theory development, complicating the social and political environment is the main precondition for the improvement and the complicating of nowadays organizational forms and types of control, realized in them. The differentiation of particular types in compliance with the fields of manifestation of the controlling function is of a particular interest in classifying the forms of control. Each field of manifestation, as a rule, supposes different circumstances that reflect upon the necessary characteristics of controlling activity, and from here - upon the used forms of control (Simeonov, 1997). The approach for the economic systems in such a classification is considered in regard to the time horizon of controlled activity, with the scope of activity and with the specialization of the activity.

Gradually, necessity of structural and subject differentiation of the strategic, tactic and operation aspects of controlling activity appears with the deepening necessity of improvement of strategic management in the development of economic systems. An expression of the trend in strategic plan is the differentiation of special subjects within the big systems that deal with strategic control. Although the process of such concrete differentiation hasn't yet gained serious dimensions, the specific tasks differentiation in the various time horizons of control is held actively within the frame of the hierarchical structure of the various control subjects. The positioning of the three types of control reflects upon their content and nature, methods and forms of realization, goals and significance of the end product. Although these forms of control are mutually supplementary, each one of them registers definitive differences.

Despite the theoretic formulating of substantial characteristics of the three types of control, it is quite difficult to specify and dose the application in a strictly defined form for control impact. Considering the dynamic internal and external environment, where systems develop, the complicated market conditions and the high clients' requirements, growing technical and technological security, the necessity of control deepens and provokes the composing of a more adequate format that combines the characteristics of more than one type of control that satisfies provocations in regard to duration and scope of activity.

At a certain stage of development of managerial thinking, the revised theoretic elaborations on grounded on suggested by practice ideas form new in content and parameter of activity form of control - managerial control. The differentiated managerial control summarizes the tasks in operative and tactic control, while widening the scope of action and significantly increasing the time horizon. This convergent form of control is a summarising category, loaded with realizing the control functions between the control of execution and the 
strategic control (tabl. 3).

Table 3. Positioning of managerial control.

\begin{tabular}{|c|c|}
\hline \multicolumn{2}{|c|}{ Positioning of managerial control in the system } \\
\hline \begin{tabular}{c} 
Managerial control \\
\hline $\begin{array}{c}\text { Higher echelon of the subjects of management } \\
\text { and control }\end{array}$
\end{tabular} \\
\hline $\begin{array}{c}\text { Medium echelon of the subjects of management } \\
\text { and control }\end{array}$ & Strategic control \\
\hline $\begin{array}{c}\text { Lower echelon of the subjects of management } \\
\text { and control }\end{array}$ & Operative control \\
\hline
\end{tabular}

Certain group of scientists (Mclntosh, 1985) engaged in the development of the idea for managerial control in content as well as in structural improvement impose their standpoint for managerial control: organizational system for searching and accumulating of information, for accountancy and feedback, established to be in contrast with so that the organization adapts to its environment change, the work behaviour of cadres measures according to criteria connected with certain sub-goals so that the difference among them could be removed or corrected.

The process of realizing managerial control is carried out on the grounds of analysis of the results of the realization of the daily tasks given to all executive cadres from the organization. The system for managerial control collects information and coordinates the combination of all activities, where these lead to the realization of particular goals. The content of the whole of this process of exercising managerial control proves also a certain change regarding combining the two interconnected activities of realizing all hierarchical levels of control, namely planning and control, while reasonable balance is realized in the managerial control system that is connected with realization of goals for a more significant as duration period (Ovcharova, 2007-a).

The updating and enrichment of modern managerial process is connected to several substantial characteristics, presented at managerial control introduction and realization:

- The value in the process, the collected and analyzed information that provokes registered necessity of actions on behaviour change realized at working feedback is considered.

- The status of the connection between control and regulating is considered, where regulating influences are exercised at given by the control data for occurred undesired changes. The essence of regulating is engaged with minimizing the differences between found and desired status of results. Realizing feedback would appear useless without regulating actions realization and the controlling process would acquire analytic-cognitive nature.

- Certain attention is paid at the realization of managerial control as a coordinated combination of the managing team's logically reckoned activities.

The role of behaviour and standardizing of particular processes and procedures criteria is promoted as direction at acquiring actions, as regulator of relations and as a factor for development and improvement of self-control in realizing the organization's goals (Terziev, Georgiev, 2017; Georgiev, 2017a; Terziev, Nichev, Stoyanov, Georgiev, 2017b).

\section{CONCLUSION}

The carried out review of the existing concepts for the status and the development of managerial control in modern organizations gives grounds for drawing the following summarizing conclusions and assessments (Terziev, Stoyanov, Georgiev, 2017c-g):

First. Within the frame of managerial science development towards the end of the 20th century, high level of maturity of theoretic understanding about control as function of management is achieved. This level of maturity has allowed the differentiation of theory of control as a significant independent branch of scientific knowledge on management. 
Second. Modern world puts managerial control realization in new circumstances, which change the stresses, the extent of significance and priority at integrating the elements of control process. These new circumstances find their expression mainly in the dynamic, radical and unexpected changes in organizations' environment. The new condition of environment leads to giving a new meaning to the understanding about managerial control as manifestation and realization of the feedback principle. Without losing its role of negative feedback that ensures the realization of the standards for executing the activities in the organizations, the managerial control increases more and more its role of positive feedback leading to change in setting goals and planning the activities. In this sense, the stress on studying control's sanction functions within the frame of the views for "the controlled organization" towards the end of the 20th century moves radically towards the study of its turning into factor for generating ideas for change within the frame of the views for "innovative organization". This trend might be reviewed as "first basic pillar" in the further development of the understandings about managerial control.

Third. Penetrating into the foothills of new economy based on knowledge and information, it changes the main factors of organizations' success. In the last years of the previous and the first years of the new century, the understanding that the growing role of immaterial assets is in the base of these factors established itself explicitly. This put the managerial control in a situation that requires theoretical rationalization at methodological and methodical level of new directions and methods for measuring the norm of systems, their factual and expected status as well as the diagnostics of deviations. A clear trend for widening the scope of controllable predominantly financial parameters outlines in the direction towards immaterial ones and for the originating from there deepening of the interdisciplinary nature of the theory of control. This trend might be reviewed as "second basic pillar" in the nowadays development of the managerial control theory.

Fourth. The study of strategic control problems towards the end of the 20th century started turning into a central problem of enriching the knowledge about managerial control. Various ways and means are searched for strategic control systems to be integrated in the theoretic systems of control on the execution and of the operative-tactic control. This trend might be reviewed as "third basic pillar" in the further progress of scientific knowledge about managerial control.

Managerial control structuring as element of the social programme would generally increase its effectiveness, and on the other hand - would contribute to finding exact and clear mechanisms as well as criteria of assessment at all levels and stages of its implementation. Defining certain mechanisms for the application of managerial control in the process of social programming is a challenge that needs complex of empiric and theoretic studies in various concrete fields.

\section{REFERENCE LIST}

Terziev, V. (2013). Vazdeystvie na politikite na pazara na truda za osiguryavane na zaetost. Izdatelstvo „Dema Pres - Ruse“, 2013 (Терзиев, В. Въздействие на политиките на пазара на труда за осигуряване на заетост. Издателство „Дема Прес - Русе“, 2013).

Terziev, V. (2014). Vazmozhnosti za povishavane na efektivnostta na sotsialnata adaptatsiya na voennosluzheshti, osvobodeni ot voenna sluzhba. Izdatelstvo „Primaks“ - Ruse, 2014 (Терзиев, B. Възможности за повишаване на ефективността на социалната адаптация на военнослужещи, освободени от военна служба. Издателство „Примакс“ - Русе, 2014).

Semenets, N. Ya. (1999). Institut sotsialynoy zashtityi voennosluzhashtih v usloviyah sotsialynogo reformirovaniya. Dis. kand. sots. nauk. - Saratov, 1999 (Семенец, Н. Я. Институт социальной защитьі военнослужащих в условиях социального реформирования. Дис. канд. соц. наук. Саратов, 1999).

Simeonov, O. (2005). Teoriyata na kontrola i deloto na prof.d.ik.n. M.Dinev, Godishnik-UNSS, Sofiya, 2005 (Симеонов, О. Теорията на контрола и делото на проф.д.ик.н. М.Динев, Годишник-УНСС, София, 2005).

Atanasov, At. (1968). Kontrol varhu stopanskata i byudzhetnata deynost, S., 1968 (Атанасов, Ат. Контрол върху стопанската и бюджетната дейност, С., 1968).

Atanasov, At., Dinev, M. (1984). Finansov kontrol, S., Nauka i izkustvo, 1984 (Атанасов, Ат., Динев, М. Финансов контрол, С., Наука и изкуство, 1984). 
Morgenthau, H. (1960). Politics Among Nations, N.Y., 1960.

Dinev, M., Hristova, L. (1992). Oditorski kontrol, S., ForKom Visulchev, 1992 (Динев, М., Христова, Л. Одиторски контрол, С., ФорКом Висулчев, 1992).

Mateev, E. (1987). Struktura i upravlenie na ikonomicheskata sistema, S., 1987 (Матеев, Е. Структура и управление на икономическата система, С., 1987).

Marks, K. (1955). Kapital, /per.s nem./, М., 1955 (Маркс, К. Капитал, /пер.с нем./, М., 1955).

Etzioni, A. (1967). Soziologie der Organisationen, M/D., 1967.

Robson, М. (2001a). Protsess resheniya problem / per.s angl./, 2001 (Робсон, М. Процесс решения проблем / пер.с англ./, 2001).

Dinev, M. (1986). Kontrol i regulirane na ikonomicheskite sistemi, S.,1986 (Динев, М. Контрол и регулиране на икономическите системи, С.,1986).

Nakata, C., Sivakumar, K. (1996). National Culture and New Product Development: An Integrative Review, Journal of Marketing, Jan. 1996.

Vilkas, E., Mayminas, E. (1981) Resheniya: teoriya, informatsiya, modelirovanie, M., "Radio i svyazy" 1981 (Вилкас, Э., Майминас, Е. Решения: теория, информация, моделирование, М., "Радио и связь" 1981).

Ross, E., (1969). Sozial control. A Survey of the Foundations Order, 1969.

Durkheim, E. (1966). Education et sociologie, Paris., 1966/4.

Merton, R. (1957). Social Theory and Social Structure, G.,1957/9.

Dinev, M., Donev, K. (1989). Usavarshenstvane na kontrola v narodnoto stopanstvo, G. Bakalov, V., 1989 (Динев, М., Донев, К. Усъвършенстване на контрола в народното стопанство, Г. Бакалов, В., 1989).

Drucker, P. (1974). Management Tasks, Responsibilities, Practices", NY, Harper and Row 1974.

Stoner and Freeman "Management" (1989a), 4th ed. Englewood Cliffs, N.J.; Prentice-Hall, 1989.

Daft, R. L., (2005). Vanderbilt University, “Management”, 6th edition, Thomson, USA, 2005.

Taylor, F. (1911). The Principles of Scientific Management, N.Y., 1911.

Worthy, J. C. (1950). Organizational Structure and Employee Morale, A S Review, 1950.

Simeonov, O. (1997). Teoretichni vaprosi na kontrola, Akadem Konsult, S., 1997 (Симеонов, O. Теоретични въпроси на контрола, Академ Консулт, С., 1997).

Ovcharova, Sn. (2007). Knowledge management in some Bulgarian organizations. 6th International congress "Knowledge Economy \& Management", 26-28 Dec.2007, Istanbul, Turkey, 2007, pp.19081915. ISSN 1308-3937.

Ovcharova, Sn. (2007a). Motivation in knowledge economy. 6th International congress "Knowledge Economy \& Management", 26-28 Dec.2007, Istanbul, Turkey, 2007, pp.1643-1651. ISSN: 1308-3937.

Mclntosh, N. (1985). The social Software of Accounting and Control Systems, N.Y., Wiley \& Sons, 1985.

Terziev, V., Georgiev, M. (2017). Highlights of the evolution of the 'Balanced Scorecard' idea as a model for managing strategy development and control. // SOCIOINT 2017- 4th International Conference on Education, Social Sciences and Humanities 10-12 July 2017- Dubai, UAE, OCERINT- International Organization Center of Academic Research, Istanbul, Turkey, 2017, pp. 607-610, ISBN: 978-60582433-1-6.

Georgiev, Marin. (2017a). The Role of the Balanced Scorecard as a tool of strategic management and control. // Journal of innovations and sustainability, Plovdiv, Bulgaria, 3, 2017, N 2, pp. 31-63, ISSN 2367-8127 (CD-ROM), ISSN 2367-8151 (on-line).

Terziev, V., Nichev, N., Stoyanov, E., Georgiev, M. (2017b). Key aspects of the problems of administrative control in Bulgaria. // Proceedings of ADVED 2017- 3rd International Conference on Advances in Education and Social Sciences 9-11 October 2017- Istanbul, Turkey. International Organization Center of Academic Research, www.ocerint.org, 2017, pp. 707-710, ISBN: 978-605-82433-0-9. 
Terziev, V., Stoyanov, E., Georgiev, M. (2017c). The factor information in the making of "the right" decision. // Scientific journal „Economics and finance“. Publishing house „BREEZE“, Current scientific research, Collection of scientific articles, Montreal, Canada, 2017, pp. 26-32, ISBN 978-617-7214-49-5.

Terziev, V., Stoyanov, E., Georgiev, M. (2017d). One solution for costs minimanization in the banking sector. // Scientific journal „Economics and finance“. Publishing house „BREEZE“, Current scientific research, Collection of scientific articles, Montreal, Canada, 2017, pp. 62-66, ISBN 978-617-7214-49-5.

Terziev, V., Stoyanov, E., Georgiev, M. (2017e). Accountable regulation of foreign exchange operations. // Scientific journal „Economics and finance“. Publishing house „BREEZE“, Current scientific research, Collection of scientific articles, Montreal, Canada, 2017, pp. 66-71, ISBN 978-617-7214-49-5.

Terziev, V., Stoyanov, E., Georgiev, M. (2017f). Specifics of control in operations with precious metals and precious stones. // Scientific journal „Economics and finance“. Publishing house „BREEZE“, Current scientific research, Collection of scientific articles, Montreal, Canada, 2017, pp. 71-76, ISBN 978-6177214-49-5.

Terziev, V., Stoyanov, E., Georgiev, M. (2017g). Intitutional team work -opportunity for improvement of financial control. // Scientific journal „Economics and finance“. Publishing house „BREEZE“, Current scientific research, Collection of scientific articles, Montreal, Canada, 2017, pp. 76-80, ISBN 978-6177214-49-5. 